\title{
The role of roots and rhizosphere in providing tolerance to toxic metals and metalloids
}

\author{
Dorina Podar ${ }^{1}$ and Frans J.M. Maathuis ${ }^{2}$ \\ ${ }^{1}$ Babes-Bolyai University \\ ${ }^{2}$ university of york
}

June 19, 2021

\begin{abstract}
Human activity and natural processes have led to widespread dissemination of metals and metalloids, many of which are toxic and have a negative impact on agronomic production. Roots, as the first point of contact, are essential in endowing plants with tolerance to excess metal(loid) in the soil. The most important root responses include: adaptation of transport processes that affect uptake, efflux and long distance transport of metal(loid)s; metal(loid) detoxification within root cells via conjugation to thiol rich compounds and subsequent sequestration in the vacuole; plasticity in root architecture; the presence of bacteria and fungi in the rhizosphere that impact on metal(loid) bioavailability; the role of root exudates. In this review we will provide details on these processes and assess their relevance for the detoxification of arsenic, cadmium, mercury and zinc. Furthermore, we will assess if any of these methodologies has been tested in field conditions and whether they are effective in terms of improving crop metal(loid) tolerance.
\end{abstract}

The role of roots and rhizosphere in providing tolerance to toxic metals and metalloids

Authors:

Dorina PODAR, Babes-Bolyai University, Faculty of Biology-Geology, Cluj 400084, Romania. Tel/Fax: 40-264-570388

Frans JM MAATHUIS, Biology Department, University of York, York YO10 5DD, United Kingdom, Tel: 441904 328652, Orcid: 0000-0001-6033-6428

Corresponding Author:

Frans JM MAATHUIS, Biology Department, University of York, York YO10 5DD, United Kingdom, Tel: 441904 328652, Orcid: 0000-0001-6033-6428

Key words: arsenic, cadmium, heavy metal, mercury metalloid, rhizosphere, root, zinc

\section{ABSTRACT}

Human activity and natural processes have led to widespread dissemination of metals and metalloids, many of which are toxic and have a negative impact on agronomic production. Roots, as the first point of contact, are essential in endowing plants with tolerance to excess metal(loid) in the soil. The most important root responses include: adaptation of transport processes that affect uptake, efflux and long distance transport of metal(loid)s; metal(loid) detoxification within root cells via conjugation to thiol rich compounds and subsequent sequestration in the vacuole; plasticity in root architecture; the presence of bacteria and fungi in the rhizosphere that impact on metal(loid) bioavailability; the role of root exudates. 
In this review we will provide details on these processes and assess their relevance for the detoxification of arsenic, cadmium, mercury and zinc. Furthermore, we will assess if any of these methodologies has been tested in field conditions and whether they are effective in terms of improving crop metal(loid) tolerance.

\section{INTRODUCTION}

Metals and metalloids are ubiquitous in the environment and mainly originate from weathering of the earth's parental rock material. Some metals play essential roles in all forms of life because they are critical for protein structure and functioning (Rosenzweig, 2002, Frausto da Silva JJR, 2001). Indeed, around 30\% of all proteins found in a cell require metal cofactors to be able to carry out vital processes such as respiration, photosynthesis, oxygen transport, nucleic acid synthesis and many others. Consequently, deficiencies of essential metals can cause severe deleterious effects in all organisms. The latter include humans many of whom suffer deficiencies for metals such as Fe (iron) and Zn (zinc) (WHO, 2013, Prasad, 2014, FAO, 2015, GNR, 2020). In contrast, non-essential metal(loids) like As (arsenic), Pb (lead), $\mathrm{Hg}$ (mercury), and $\mathrm{Cd}$ (cadmium) are also ubiquitous in many environments. These are ranked as highly toxic substances for humans according to the Agency for toxic substances and disease (ATDSR, 2019). Uptake of these elements can be via skin contact or by breathing in fumes in the case of $\mathrm{Hg}$ or $\mathrm{Pb}$, but ingestion through contaminated diets is the main mechanism. In particular, consumption of plants, shellfish and fish are important routes for human intake of toxic elements such as $\mathrm{As}, \mathrm{Cd}, \mathrm{Hg}$ and $\mathrm{Pb}$. Some of the afflictions associated with metal(loid) poisoning are neurological impairment of the central nervous system ( $\mathrm{As}, \mathrm{Pb}, \mathrm{Hg}$ ), coronary and vascular disease leading to cardiac arrest $(\mathrm{As}, \mathrm{Cd}, \mathrm{Hg}, \mathrm{Pb})$, osteoporosis $(\mathrm{Cd})$, renal failure $(\mathrm{Cd}, \mathrm{Hg})$, respiratory failure and gastrointestinal lesions (Hg), and cancer (As, Cd) (Chaney, 2015; )see (Renu et al., 2021) for review).

In plants, essential micronutrients include the metals Co (cobalt), $\mathrm{Cu}$ (copper), Fe (iron), $\mathrm{Mn}$ (manganese), Mo (molybdenum), Ni (nickel) and Zn, and the metalloid B (boron). In addition, the metalloid Si (silicon) has growth promoting effects in many species (Thorne et al., 2020). Other elements are frequently encountered which have no biological function, typically become toxic at low soil concentrations, and have a negative impact on plant growth and development. These include metals such as Cd, Cr (chromium), Cs (cesium), $\mathrm{Hg}, \mathrm{Pb}$ and metalloids like $\mathrm{As}$ and $\mathrm{Sb}$ (antimony), all of which can occur at toxic levels due to natural processes and anthropogenic activities. Examples of natural activities include weathering of ultramafic rocks that leads to the formation of serpentine soils that contain high concentrations of heavy metals like $\mathrm{Cr}, \mathrm{Ni}$, Co and Fe (Chiarucci and Baker, 2007, Tashakor et al., 2013) or the leaching of As from igneous rock that leads to contamination of aquifers and groundwater.

Post industrial revolution human activities have become an important vehicle for the dissemination of metals in the environment through the use of pesticides and herbicides, mining, smelting, waste disposal, application of inorganic fertiliser and, more recently, use of nanoparticles (Bundschuh et al., 2018, Wilson, 2018). These undertakings have led to wide scale contamination of agricultural soils: For example, it is estimated that more than $6 \%\left(\sim 137,000 \mathrm{~km}^{2}\right)$ of the agricultural soils in Europe are in need of remediation because of metal(loid) contamination (Tóth et al., 2016). Agriculture itself has greatly contributed to this problem; many herbicides, pesticides and preservatives contain $\mathrm{Cu}, \mathrm{Hg}, \mathrm{Mn}, \mathrm{Pb}, \mathrm{Zn}$ or $\mathrm{As}$, such as copper sulphate and lead arsenate used in fruit orchards, arsenic compounds used for banana pest control and cotton defoliation (Wuana and Okieimen, 2011), or the application of wood preservative to fence posts (McLaughlin et al., 2000). Repeated application of inorganic phosphate fertiliser can significantly increase As deposition while treating soils with sewage, manure and other biosolids is another mechanism that causes accumulation of $\mathrm{Cd}, \mathrm{Cr}, \mathrm{Cu}, \mathrm{Ni}$ and Zn (Basta et al., 2005, Keller et al., 2002).

Metal(loid) pollution is a global and increasing menace that negatively affects plant growth and development. In an agronomic context, this leads to large yield losses (e.g. (Kotecha et al., 2019) and it is therefore imperative to develop crops with better metal(loid) tolerance. In this paper we will summarise some of the generic responses of plants to toxic heavy metal(loids), using arsenic, cadmium, mercury and zinc to respectively represent metalloids, non-volatile heavy metals, volatile heavy metals, and metallic micronutrients 
that become toxic at high levels. We will also highlight the specific response mechanisms that differentiate these elements. Based on these analyses, we will critically evaluate scenarios that are likely to contribute to crop metal(loid) tolerance with a focus on the role of roots and the rhizosphere in metal(loid) detoxification.

\section{METAL TOXICITY; SIMILARITIES IN MECHANISMS AND RESPONSES}

In general, metal toxicity has two main effects; firstly, it interferes with nutrient homeostasis and secondly it causes secondary stress particularly in the form of oxidative damage. Some metal(loid)s are nutrients in their own right but may be present at toxic levels. Other metal(loid)s share chemico-physical properties with essential nutrients, and thus affect nutrient homeostasis by disrupting their uptake and distribution. Furthermore, metal(loid)s can affect enzyme activity by competing with physiological metal cofactors. This is particularly the case with elements that have identical charge and similar ionic radius, for example $\mathrm{Cd}^{2+}$ and $\mathrm{Ca}^{2+}$ (calcium). The propensity to alter the cellular redox potential, through binding with thiol groups and/or through production of reactive oxygen species, means metal(loid)s are prone to cause oxidative stress. Thus, faced with toxic levels of harmful metals and metalloids plants show great similarities in their responses which are summarised in Figure 1 and further discussed below.

The role of root exudates: Roots extrude $\mathrm{H}^{+}$(protons) and carbon compounds such as organic acids, phenols and phytosiderophores to promote solubility of essential nutrients (Bali et al., 2020). $\mathrm{H}^{+}$lower the rhizosphere $\mathrm{pH}$ which increases soil mineral solubility and hence the release of essential nutrients such as Fe, $\mathrm{P}$ (phosphorus), $\mathrm{Ca}, \mathrm{Mg}$ and $\mathrm{S}$ (sulfur), but also the release of toxic metals. Organic exudates have negatively charged reactive groups such as sulfhydryls, carboxyls and hydroxyls with a high affinity for metals. For example, root exuded citrate and malate are known to chelate various metals such as $\mathrm{Al}$ (aluminium), $\mathrm{Cd}$ and $\mathrm{Pb}$. Exudation levels typically increase in response to metal presence but the details are species related. Thus in sorghum exposure to $\mathrm{Cd}$ augmented malate extrusion whereas the same heavy metal induced citrate release in maize roots (Pinto et al., 2008). Phenolics are a further compound that is often released by plant roots in response to heavy metal stress. The hydroxyl group of these aromatic molecules can bind metals (Guo et al., 2016). In general, phenolic and organic acid-metal complexes are not taken up by the plant and hence lower soil toxicity by reducing metal(loid) bioavailability.

Metal(loid) chelation: Two major cellular ligands that prevent the occurrence of metals in ionic (reactive) form are glutathione and phytochelatin (Figure 2). Both contain sulfhydryl groups with high affinity for metal binding (Singh et al., 2016). Phytochelatin is a glutathione oligomer with a structure that consists of multiple $\gamma$-glutamate-cysteine moieties, followed by a terminal glycine. The formation of phytochelatins is influenced by the presence of heavy metal(loid)s and under control of the phytochelatin synthase enzyme. Metallothionein is another glutathione-based, cysteine-rich protein that binds metal. Its expression is raised in response to heavy metal stress. Lastly, amino acids like histidine can bind metals and appear particularly important for xylem mediated translocation of metals like Ni and Zn (Kozhevnikova et al., 2014a, Kozhevnikova et al., 2014b).

Vacuolar sequestration: The relative lack of biochemical machinery in the vacuole means it is the preferred cellular storage compartment for toxic metal(loid)s. The transport of metal(loid)s complexed to glutathione or phytochelatins across the tonoplast is carried out by tonoplast ATP-Binding-Cassette (ABC) transporters that are members of the ABCC family (Song et al., 2014). Tonoplast ABC transporters for liganded metal(loid)s are expressed in many tissues. In rice this includes roots, leaves, nodes, peduncles and rachis and $\mathrm{ABC}$ proteins are instrumental in the vacuolar sequestration of $\mathrm{Cd}$, $\mathrm{As}$ and a range of other metals (Clemens and Ma, 2016). Vacuolar deposition of metals in ionic form also occurs and can be mediated by members of the Cation Diffusion Facilitator family known in plants as MTP (Metal Tolerance Protein) family (Clemens and Ma, 2016). Metal(loid) storage in root vacuoles is also an important factor to prevent large scale translocation of metal(loid)s to above ground tissues.

Alteration of root architecture: Root architecture is sensitive to metal toxicity. This includes biosynthesis of suberin and lignin to strengthen the exo- and endodermic barriers that limit apoplastic transfer (Figure 2). Callose deposition also reduces root metal(loid) permeability. Furthermore, root architecture alteration 
in the presence of heavy metals often involves the root 'avoidance response', i.e. the propensity to either stop growth or grow away from polluted substrates. Root avoidance has been observed in many species for multiple metals including Zn, Ni and Cd (Tognacchini et al., 2020). The opposite response can be found in hyperaccumulators where roots actively forage for metals by increased rooting in soil patches with high metal content (Whiting et al., 2000).

Oxidative stress: Increased levels of heavy metal(loid)s lead to oxidative stress by generating reactive oxygen species (ROS) that can cause lipid oxidation and DNA damage (Noctor et al., 2016). This is countered by increased levels of enzymatic antioxidants like superoxide dismutase, catalase and ascorbate peroxidase, and non-enzymatic antioxidants like tocopherol, glutathione, phenolic compounds and amino acids such as proline. Many studies have shown improved metal(loid) tolerance when the genes and pathways that encode these factors are upregulated (e.g. (Bhaduri and Fulekar, 2012). For example, proline accumulation was observed in rice plants exposed after exposure to $\mathrm{Hg}$ stress (Hayat et al., 2012).

\section{METAL(LOID) SPECIFIC TOXICITY AND DETOXIFICATION}

\section{Arsenic}

Arsenic is a toxic metalloid. It is the 20th most abundant element in the Earth's crust and universally present in the environment. It has a number of therapeutic applications but is generally toxic to all living organisms and classed as a carcinogen by the WHO. Acute arsenic poisoning is relatively rare but chronic poisoning is widespread with over 200 million humans running the risk of arsenic poisoning. The latter is particularly an issue in South-east Asia where the local geology creates considerable arsenic pollution of ground and surface waters.

Arsenic primarily occurs as the inorganic trivalent arsenite (AsIII) and pentavalent arsenate (AsV). Low levels of organic As species also occur such as methylated or dimethylated arsinic acid. The latter are generally considered to be less toxic and therefore are not further considered in this paper. AsV is chemically similar to phosphate $(\mathrm{Pi})$ and causes toxicity by disturbing oxidative phosphorylation, ATP synthesis and a host of metabolic processes that rely on Pi biochemistry. AsIII toxicity is much greater than that of AsV. AsIII in solution takes the form of neutral arsenous acid, and has a similar size to that of essential nutrients such as boric acid and silicic acid. AsIII has a strong propensity to bind sulfhydryl groups and consequently affects general aspects of protein functioning by interfering with secondary, tertiary and quaternary protein structure and with protein-protein interactions.

Although As contamination often derives from geological sources such as marine sedimentary rocks, it is also widely disseminated via human activity such as combustion of coal, the use of pesticides and herbicides, mining or the application of (phosphate) fertiliser. The often encountered contamination of irrigation water inevitably leads to crop exposure to arsenic which depresses plant growth and crop yields.

Plants readily take up inorganic As and a substantial proportion of it can be translocated to edible parts such as the grain of cereals (Zhao et al., 2009, Meharg and Rahman, 2003). Dietary intake of As is particularly relevant in the case of rice (Tripathi et al., 2007).

Processes in the rhizosphere related to arsenic toxicity As stated above, As in the soil is primarily present in the form of inorganic AsIII (as neutral $\mathrm{AsOH}_{3}$ ) and $\mathrm{AsV}$ (as $\mathrm{AsO}_{4}{ }^{2-}$ ). The AsIII-AsV balance depends on the redox potential; for example, paddy rice is cultivated in flooded conditions which are typically reductive and hence rice is exposed predominantly to AsIII. In contrast, aerated soils tend to be oxidative and show a prevalence of $\mathrm{AsV}$.

Soil redox potential is affected by and greatly impacts on the rhizosphere microbial communities. Considerable research has been carried out to assess the role of mycorrhizas in plant As tolerance. Mycorrhizas have been found to promote plant growth in As rich substrates. Mechanistically this may be indirect, i.e. based on their capability to contribute to plant Pi. Adequate Pi supply typically leads to downregulation of Pi uptake systems and consequently reduced As accumulation since AsV is taken up by the same machinery. For example in soybean, establishment of arbuscular mycorrhizas not only significantly promoted plant growth, 
it greatly reduced the concentration of tissue As in both shoots and roots. Other work hints at a general reduction by mycorrhization of plant oxidative stress (e.g. (Spagnoletti et al., 2016) but how this would work mechanistically is unclear. Yet other work points to the impact of mycorrhizas on transcript level of Pi transporters and metallothioneins ( $\mathrm{Li}$ et al., 2018). The latter may help lowering As translocation from root to shoot. However, caution should be applied when interpreting these findings; many of these studies find positive effects of mycorrhization in control conditions, which makes it difficult to assess the exact role of mycorrhizas in plant As tolerance.

In both aerobic and anaerobic conditions, As speciation and mobility are also greatly influenced by the bacterial species that populate the rhizosphere. Both arsenite oxidising and arsenate reducing bacteria influence the chemical form and bioavailability of As. Since AsIII is considerably more toxic to plants than AsV, AsV reduction can greatly increase overall As toxicity whereas on the other hand As oxidising bacteria could play a protective role towards plants. Like plants, many rhizosphere fungi and bacteria produce chelates that remove considerable amounts of soil As from the bioavailable fractions (Nair et al., 2007). Excreted (polymeric) substances such as polysaccharides, glycoproteins, lipopolysaccharides, soluble peptides and organic acids are strong metal(loid) chelators that reduce bioavailability. Furthermore, ligands in the form of metallothioneins and phytochelatins allow microorganism to detoxify and store metal(loid) either as a cellular fraction or, in the case of fungi, via deposition in the vacuoles.

Aquatic plants release oxygen from their roots that catalyses the conversion of the relatively soluble $\mathrm{Fe}^{2+}$ to the insoluble $\mathrm{Fe}^{3+}$. The latter causes precipitation of iron-oxides and iron-hydroxides at the root surface creating a brownish plaque that has high affinity for metals and metalloids such as As. Thus, iron plaques can immobilise the otherwise mobile As fraction in soils and as such lower As bioavailability by $\sim 5-10 \%$ (Maisch et al., 2020).

Iron plaque formation is partially controlled by the amount of oxygen release by roots but also by the microbial community; in the presence of $\mathrm{Fe}^{3+}$-reducing bacteria a large proportion of the plaque can be dissolved, remobilising plaque metal(loid)s (Maisch et al., 2020). However, AsIII-oxidising bacteria normally form the majority of iron plaque microbes and they promote precipitation and immobilisation of As (Hu et al., 2015, Yu et al., 2017).

Arsenic uptake and distribution The molecular mechanism of As uptake at the soil:root boundary depends on the chemical form of As. AsV enters plants primarily via (active) Pi transporters (Figure 3) that are energised via coupling to the proton gradient. Consequently, As tolerance is closely associated with Pi uptake capacity and loss of function in Pi transporters typically improves As tolerance (Remy et al., 2012). Uptake of AsIII is passive and primarily mediated by NIPs (nodulin-26-like intrinsic proteins) a class of aquaporins (Lindsay and Maathuis, 2017) (Figure 3). Other members of the aquaporin family (e.g. plasma membrane intrinsic proteins or PIPs and tonoplast intrinsic proteins or TIPs) may also contribute but are likely to play a minor role (e.g. (Mosa et al., 2012). AsIII uptake is sustained by active efflux towards the stele through efflux transporters such as Lsi2 which are anion permeases from the ArsB/NhaD superfamily. In rice, Lsi2 is localised to the proximal side of the exo- and endodermal cells (Ma et al., 2008) in the root. Loss of function in NIPs and/or in Lsi2-type transporters results in markedly reduced uptake of As (Ma et al., 2008). As efflux in roots is considerable (Ali et al., 2012, Duan et al., 2012) but the underlying mechanism is unknown.

Arsenic concentrations in root tissues tend to be 5 to 20 -fold higher than those found in shoots, (e.g. (Lindsay and Maathuis, 2016)). The identity of the proteins that are responsible for this long distance movement of As are unknown though specific members of the Pi transporter family and specific NIPs probably play a role. The observation that phloem often contains significant amounts of As suggests that net deposition of As in the shoot could be lowered by recirculation via the phloem. Phloem mediated As distribution is also of importance in the context of As partitioning to edible parts of the plant (Lindsay and Maathuis, 2017).

Cellular detoxification of arsenic Cellular detoxification of As is complex. It generally comprises reduction, chelation and sequestration. In most organisms, including plants grown in aerobic conditions, the initial response is the reduction of AsV to AsIII (Figure 3). Consequently, cellular arsenic is predominantly found 
as AsIII in plants. A number of arsenate reductases has been reported in the literature (e.g. (Xu et al., 2017). These enzymes use glutathione as reductant and are often encoded by ATQ1/HAC1 . ATQ1 is expressed predominantly in the root hairs, epidermal cells and the stele (Chao et al., 2014) and loss of function mutations in $A T Q / H A C$ genes leads to increased sensitivity to AsV but not AsIII. Surprisingly, ATQ/HAC proteins not only influence the cellular AsIII/AsV ratio but also have a remarkable effect on root As efflux and As translocation to the shoot. Reduction of AsV to AsIII is a precondition for chelation of AsIII by glutathione and phytochelatins. Liganded AsIII complexes are then stored in root vacuoles which further neutralises the arsenic species in terms of potential cellular harm.

\section{Cadmium}

Cadmium has atomic number 48 , an atomic weight of 112 , a density of $8.65 \mathrm{~g} / \mathrm{cm}^{3}$ and appears as a silvery bluish-grey metal. Cadmium levels in uncontaminated soils are very low $(<1 \mathrm{ppm})$ whereas polluted soils can contain over $50 \mathrm{ppm}$. Contamination is largely due to human activities such as discharge and emission from industry, mining, use of sewage sludge and Pi fertilisers and application of $\mathrm{Cd}$ containing pesticide. $\mathrm{Cd}$ polluted agricultural soils are ubiquitous and found on all continents and Cd exposure suppresses germination, inhibits plant growth and reduces agricultural yields. Cadmium is highly toxic to most plants with toxicity symptoms occurring when tissue levels are a few ppm.

Processes in the rhizosphere related to Cd toxicity Dissolved, bioavailable Cd is typically found in its ionic form $\left(\mathrm{Cd}^{2+}\right)$. Whether the concentration of $\mathrm{Cd}$ in the soil solution becomes toxic will depend greatly on multiple processes that take place in the rhizosphere. Cd chelation is an important aspect of detoxification. Chelation occurs via several ways; plant released organic acids and phytosiderophores can remove some of the soluble $\mathrm{Cd}$ fraction from the soil solution though siderophore production may only be significant during Fe stress (Bali et al., 2020). Organic acids and phenolic compounds also bind considerable amounts of Cd (Pinto et al., 2008, Guo et al., 2016).

Binding of $\mathrm{Cd}$ in the apoplast is another mechanism that may contribute to imobilising Cd. Especially cell wall components like pectins contain large numbers of carboxyl and hydroxyl groups. Apposing carboxyl and carbonyl groups are typically bridged by divalent $\mathrm{Ca}^{2+}$ via electrostatic interactions, but $\mathrm{Cd}^{2+}$ can substitute $\mathrm{Ca}^{2+}$ in this process. Binding to the root cell wall could provide an explanation for the often-observed linear component of Cd uptake kinetics (Lux et al., 2011).

Strategies to imobilise free $\mathrm{Cd}$ can also include the use of plant-growth-promoting rhizobacteria (PGPR). Many Cd-tolerant soil bacteria have been identified within the genera of Pseudomonas, Bacillus, Arthrobacter and Ralstonia. These microbes can have a profound effect on the Cd bioavailability and thus plant toxicity. Like their plant counterparts, microbes can alter the rhizosphere $\mathrm{pH}$ and therefore $\mathrm{Cd}$ solubility. As mentioned above for the root apoplast, adsorption and binding at the bacterial cell surface can take place at negative groups such as $\mathrm{NH}_{2}{ }^{-}, \mathrm{COOH}^{-}, \mathrm{OH}^{-}, \mathrm{PO}_{4}{ }^{3-}$, and $\mathrm{SO}_{4}{ }^{2-}$ and thereby lower the metal content in the rhizosphere.

Mycorrhizal fungi also can improve plant tolerance to heavy metals. Some of the mechanisms discussed above such as adsorption to the cell surface may play a role as will hyphal uptake of metals which reduces their soluble fraction. However, it appears that mycorrhizal fungi can also impact on metal compartmentation of the plant host; in Lotus japonicus Cd immobilisation in plant roots was observed which led to a significant reduction in shoot $\mathrm{Cd}$ (Chen et al., 2018). This shows that mycorrhizal fungi may be important for the phytostabilisation of $\mathrm{Cd}$-contaminated soil, possibly via altering transport pathways of $\mathrm{Cd}$ in the host.

Cadmium uptake/distribution $\mathrm{Cd}^{2+}$ uptake typically has a $\mathrm{Km}$ value in the nanomolar range and its sensitivity to the presence of other cations such as $\mathrm{Ca}, \mathrm{Fe}, \mathrm{Zn}$ and $\mathrm{Mn}$ points to substrate competition (but this may occur at multiple transport sites) (Cataldo et al., 1983). Proteins that mediate $\mathrm{Cd}^{2+}$ influx are members of the ZIP (Zinc regulated transporter/Iron-regulated transporter-like Protein) family (Clemens and Ma, 2016). Some authors also mention non-selective cation channels and low affinity cation transporters (LCT1) as possible pathways for Cd entry (e.g. (Greger et al., 2016) but the latter seems unlikely given that the ambient $\mathrm{Cd}$ concentration is typically micromolar while competing cations like $\mathrm{Na}, \mathrm{K}$ and $\mathrm{Ca}$ are 
present at much higher concentrations. Complexed forms of $\mathrm{Cd}$ require different uptake mechanisms; in the form of chelates such as Fe-Cd-siderophores or Cd-nicotianamine, influx takes place via YSL (Yellow-Stripe 1-Like) proteins (Feng et al., 2017).

The majority of $\mathrm{Cd}$ that enters the plant becomes sequestered in the root. This can occur through apoplastic adsorption or through vacuolar deposition (Figure 3). The transport mechanism for vacuolar storage also depends on the chemical form of $\mathrm{Cd}$. The divalent ion likely competes with $\mathrm{Ca}^{2+}$ and/or $\mathrm{Zn}^{2+}$ at binding sites of transporters that are normally involved in the transport of these nutrients. Thus vacuolar uptake of $\mathrm{Cd}^{2+}$ can be catalysed by tonoplast cation:proton antiporters from the CAX family and Zn transporters of the MTP family. More selective heavy metal ATPases of the HMA (Heavy Metal ATPase) family that transport $\mathrm{Cd}^{2+}$ form another pathway for vacuolar storage. Complexed forms of cytoplasmic Cd consist of $\mathrm{Cd}$ bound to glutathione and phytochelatin and these Cd-species rely on the activity of $\mathrm{ABC}$ transporters from the C subfamily for vacuolar storage (Zhang et al., 2018). Vacuolar Cd release is likely via NRAMP (Natural-Resistance Associated Macrophage Proteins) type transporters (Song et al., 2017). Release of Cd into the xylem for translocation to the shoot depends on HMA ATPases (e.g. (Fontanili et al., 2016). For example, HMA3 is primarily expressed in the root and a major determinant of leaf $\mathrm{Cd}$ accumulation in Arabidopsis and rice (Chao et al., 2012).

Cellular detoxification of $C d$ Reducing the amount of $\mathrm{Cd}$ that enters the plant symplast and partitioning into less sensitive organs and organelles form a potent mechanism to reduce cellular toxicity. This critically depends on the activity of multiple membrane transporters (Figure 3). Gene expression and genomic association studies do show different transporter alleles and expression levels between plants that vary in $\mathrm{Cd}$ tolerance (Zhang et al., 2018). For example, expression of AtABCC3 is induced in response to Cd treatment, augmenting the vacuolar sequestration of phytochelatin bound Cd (Zhang et al., 2018). A rice QTL study showed that weak and non-functional alleles of HMA3, which mediates vacuolar Cd sequestration, caused increased Cd translocation to the shoot and a 'high accumulator' phenotype (Ueno et al., 2010). Overexpression of proteins involved in the production of chelating agents improves Cd tolerance (Zanella et al., 2016). Similarly, regulatory proteins such as transcription factors have been identified (Shim et al., 2009) such as HsfA4a in wheat and rice, that increase biosynthesis of metallothioneins.

\section{Mercury}

Mercury occurs in the environment in metallic, ionic and organic forms. $\mathrm{Hg}$ released from aquatic and terrestrial environments into the atmosphere is mostly in its gaseous elemental state, $\mathrm{Hg}^{0}$. In the atmosphere, $\mathrm{Hg}^{0}$ is slowly oxidized to the inorganic mercuric state, $\mathrm{Hg}^{2+}$, which is subsequently returned to land and water through wet and dry deposition (Raj and Maiti, 2019, ATSDR, 1999). Thus, the quantity of Hg deposited onto the soil surfaces or in the water increases with every new wave of aerial deposition. In addition, wet or dry aerial deposition recirculates the air-born $\mathrm{Hg}$ gas previously emitted into the atmosphere as a by-product of diverse industrial emissions (Gworek et al., 2020, Vallee and Ulmer, 1972). In particular, organic mercuric compounds such as methyl-, ethyl-, dimethyl- and diethyl-mercury, which are generated both through abiotic and biotic processes, are highly toxic. $\mathrm{Hg}$ is not metabolised, nor is it excreted, causing its bioconcentration and accumulation via food chains. For example, many instances are known of methylmercury bioconcentration via aquatic food webs particularly those based on sea food (Kumari et al., 2020, Leterme et al., 2014, Silver and Hobman, 2007). Human poisoning through inhalation, oral ingestion or uptake through the skin can manifest itself at intake levels as low as $3 \mu \mathrm{g} \mathrm{kg}^{-1}$ day $^{-1}$ (ATDSR, 2019).

Processes in the rhizosphere related to mercury toxicity Within soils $\mathrm{Hg}$ is found in multiple forms depending on organic acids, $\mathrm{pH}$, bedrock composition and biotic factors. $\mathrm{Hg}$ is often bound to negative, reactive groups such as sulfhydryls, carboxyls, phenols and alcohols that form a major component of humic or fulvic acids. This promotes formation of $\mathrm{HgS}$ (mercuric sulfide, cinnabar), $\mathrm{HgCl}_{2}$ (mercuric chloride) and $\mathrm{Hg}(\mathrm{OH})$, the sulfide being the least soluble (USEPA; United States Environmental Protection Agency, 2007). Mercury ions can also be integrated into carbon skeletons in the form of organomercurials. Soil microbes interfere with $\mathrm{Hg}$ forms and bioavailability; microorganisms can enable $\mathrm{Hg}^{2+}$ release from complexed forms in the soil through protonation mediated by $\mathrm{H}^{+}$-ATPases, chelation via organic acid secretion, siderophore production, 
and chemical transformation and volatilization, commonly achieved by mercuric reductase, (e.g. (Artz et al., 2015). Biological conversion of the $\mathrm{Hg}^{2+}$ into methyl-Hg, mainly carried out by anaerobic bacteria, leads to integration into the food chain (ATSDR, 1999, Cao et al., 2021, Ma et al., 2019).

Mercury uptake and distribution Plant root cells take up $\mathrm{Hg}$ as a linear function of the ambient concentration and specific membrane transporter proteins to catalyse the transmembrane movement of $\mathrm{Hg}$ have not been identified. The lipophilic nature of elemental and organic mercurials implies that these forms may simply diffuse across the lipid bilayer. It is feasible that ionic $\mathrm{Hg}^{2+}$ is not taken up as such but may rely on (microbial) reduction to $\mathrm{Hg}^{0}$ before it can enter the root symplast. Within the symplast, the high affinity of $\mathrm{Hg}$ for thiol groups directs it towards cysteine residues.

Only a small fraction of total $\mathrm{Hg}$ is translocated to the leaves $\left(<0.3 \%\right.$ for $\mathrm{Hg}^{2+}$ and $<3 \%$ for $\mathrm{MeHg}$ ) and most of the accumulated $\mathrm{Hg}$ remains in the roots for two main reasons (Schwesig and Krebs, 2003): Firstly, $\mathrm{Hg}^{2+}$ can be ligated to sulfhydryl, hydroxyl and carboxyl groups of compounds such as organic acids (Riddle et al., 2002) and sulphur-rich structural proteins of the cell wall such as extensins and expansins (Carrasco-Gil et al., 2013) that are present in the root apoplast. Secondly, Hg can electrostatically interact with anionic compounds such as phosphates, carbonates and sulfates to form insoluble precipitates that limit symplastic mobility.

Cellular detoxification of mercury Mercury detoxification largely depends on vacuolar sequestration, with phytochelatins as intermediates and members of the ABCC family that catalyse vacuolar deposition. In the vacuolar lumen $\mathrm{Hg}-\mathrm{PC}$ complexes can be converted into crystals, largely neutralising intracellular toxicity (Carrasco-Gil et al., 2011).

Although more problematic with transition elements such as $\mathrm{Pb}$ and $\mathrm{Cd}, \mathrm{Hg}$ does generate oxidative stress. This notion is supported by multiple transcrptomics studies that report increased activity of enzymatic and non-enzymatic antioxidants. An example is a study on Medicago sativa exposed to $30 \mu \mathrm{M} \mathrm{Hg}$ (OrtegaVillasante et al., 2005); plants showed abrupt cessation of growth and cell necrosis within the first $24 \mathrm{~h}$, while the subsequent depletion of glutathione and lipid and protein oxidation were accompanied by strong induction of antioxidant enzymes such as SOD, POX and APX (Zhou et al., 2007).

\section{Zinc}

Zinc is an essential micronutrient for plant growth and development. It acts as a cofactor of more than 300 proteins which primarily are zinc-finger proteins, DNA polymerases and RNA polymerases. In these enzymes Zn regulates catalytic activity, conformational stability, protein folding and protein interactions (particularly with nucleic acids) (Kambe et al., 2015). Remarkable is also the function of $\mathrm{Zn}$ in the stabilisation of biomembranes and its crucial role in lipid and nucleic acid synthesis. However, in higher concentrations Zn can become toxic for plants, harming growth, development and a host of essential functions. In A. thaliana, treatment with concentrations above $0.1 \mathrm{mM}$ are toxic (Marschner, 2012, Jain et al., 2013).

Processes in the rhizosphere related to $\mathrm{Zn}$ toxicity At the root, $\mathrm{Zn}$ is taken up predominantly as a divalent cation $\left(\mathrm{Zn}^{2+}\right)$. However, it can also bind to organic ligands and enter the root as a chelation complex. Depending on the ligand, this can occur through lowering the $\mathrm{pH}$ by extrusion of $\mathrm{H}^{+}$and/or organic acids to enhance the solubility of $\mathrm{Zn}$-complexes such as $\mathrm{Zn}$ phosphates to release $\mathrm{Zn}^{2+}$. Subsequently $\mathrm{Zn}^{2+}$ can then be absorbed by the epidermal cells of the roots. The second strategy is based on exudation of phytosiderophores. $\mathrm{Zn}^{2+}$ uptake from the soil solution is driven by the negative membrane potential of root cells. Mycorrhizas also contribute to $\mathrm{Zn}$ uptake in plants. As much as $24 \%$ of the shoot $\mathrm{Zn}$ in wheat and tomato and $12 \%$ in barley are provided through the arbuscular mycorrhizal fungi (Coccina et al., 2019, Watts-Williams et al., 2015).

Zinc uptake and distribution Zn homeostasis in plantaconsists of a complex of cellular functions such as uptake, efflux, accumulation, sequestration, remobilization and detoxification (Figure 3). Membrane transporters that catalyse the movement of $\mathrm{Zn}^{2+}$ mostly belong to the ZIP family. ZIPs are expressed in multiple membranes and tissues including roots, leaves, nodules and flowers and typically transport $\mathrm{Zn}^{2+}$ from the 
extracellular space to the root symplast or from organellar lumens into the cytoplasm (López-Millán et al., 2004, Krishna et al., 2020). ZIP proteins have a histidine-rich domain, which might be involved in metal binding and transport regulation (Jeong and Eide, 2013, Zhang et al., 2019).

Expression of ZIPs and other transporters is strictly regulated in order to provide the necessary quantity of Zn into all cell types and at all stages of development. Several transcription factors involved in Zn homeostasis belong to the F group of the basic-region leucine zipper (bZIP) factors and have histidine-rich motifs at their $\mathrm{N}$-terminal region capable of Zn binding. Thus, bZIPs act as Zn sensors that are crucial in maintaining adequate Zn acquisition (Krishna et al., 2020, Lilay et al., 2021).

In addition to ZIPs, Zn uptake can occur in the form of Zn phytosiderophores, mediated by members of the YSL transporter family (von Wiren et al., 1996, Erenoglu et al., 2000, Suzuki et al., 2006).

Translocation of $\mathrm{Zn}$ from roots to the above ground organs via the xylem is catalysed by members of P1btype ATPases, localized to the plasma membrane cells in the root pericycle. HMAs such as AtHMA2 and AtHMA4 actively upload Zn and Cd into the xylem (e.g. (Verret et al., 2004, Hanikenne et al., 2008, Migeon et al., 2010, Wong et al., 2009).

The tonoplast HMAs are involved in the vacuolar accumulation of metals such as $\mathrm{Cd}$ and $\mathrm{Zn}$ (Morel et al., 2009) whilst remobilisation of Zn from the vacuoles is carried out by ZIP and NRAMP transporters. For instance, the tonoplast localised AtZIP1 releases Zn and Mn from the vacuolar lumen, presumably for subsequent long distance transport in the xylem (Milner et al., 2013).

Cellular detoxification of $Z n$ To avoid the damaging effects of metal toxicity a fine balance of processes is necessary to maintain cytosolic metal concentration. A significant part of that is the use of vacuoles as a storage buffer. This is an important characteristic of the root cells for they are able to prevent translocation of toxic ions to the shoot. The loading of $\mathrm{Zn}^{2+}$ into vacuoles is facilitated by members of the Cation Diffusion Facilitator Family known in plants as MTPs that are located in the tonoplast (Arrivault et al., 2006, Gustin et al., 2009, Tanaka et al., 2013). Within the cytosol the exchangeable $\mathrm{Zn}^{2+}$ fraction is rapidly bound to ligands such as nicotianamine (NA), histidine, glutathione, phytochelatin or phosphate (Clemens, 2019). Conjugated and liganded $\mathrm{Zn}^{2+}$ is subsequently moved into the vacuole by $\mathrm{ABC}$ transporters and vacuolar sequestration in this manner is an important factor for retaining most $\mathrm{Zn}$ in the root. However, vacuolar sequestration of $\mathrm{Zn}^{2+}$ (but also of $\mathrm{Cd}^{2+}, \mathrm{Co}^{2+}$ and $\mathrm{Pb}^{2+}$ ) is further achieved through HMA ATPases such as HMA3 in Arabidopsis thaliana (Morel et al., 2009), while excess $\mathrm{Zn}$ in this species leads to upregulation of the Zinc-Induced Facilitator 1 (AtZIF1), a vacuolar Zn-NA importer into the vacuole (Haydon and Cobbett, 2007).

\section{MULTIPLE SCENARIOS TO IMPROVE METAL TOLERANCE}

From the previous sections it is clear that metal(loid) tolerance and detoxification is a multigenic phenomenon that is based on a plethora of mechanisms. Thus, the scope for improving tolerance and detoxification is enormous; on the one hand it includes generic routes such as adaptation of root architecture, improved antioxidant response and greater deposition of metal(loid)s in root vacuoles, and on the other hand, more specific processes such as the use of metal(loid)-specific microbes or alterations in transport for a particular element. Which approach is the most likely to be successful will depend on many factors, for example whether contamination comes from a specific metal(loid) or from multiple elements, whether the aim is to improve tolerance to increase yield or, for instance, to allow greater metal accumulation for remediation purposes. In the subsequent sections we will show examples of how metal tolerance has been successfully enhanced and provide a more detailed discussion of root based processes that look particularly promising.

Metal(loid) liganding and vacuolar sequestration Detoxification of heavy metal(loid)s in some cases requires reductant (e.g. in the case of $\mathrm{Hg}$ and $\mathrm{As}$ ) but, since vacuolar deposition is typically in the form of metal(loid) complexes, relies on liganding to organic thiol groups that are found on compounds such as glutathione and phytochelatins. Many studies tested the effect of upregulating one or more of the components of this process; e.g. overexpression of reductases (Shi et al., 2016) or ABC transporters for vacuolar sequestration 
of metal(loid)s (Zhang et al., 2018). The outcomes of these studies are sometimes counterintuitive: Increased expression of phytochelatin synthases increased tolerance for As in several species but also causes Cd hypersensitivity in many cases ( $\mathrm{Li}$ et al., 2004). This is possibly to do with different metal(loid)s requiring specific phytochelatins. Alternatively, there may be an imbalance between Cd liganding and subsequent transport into the vacuole. Either way, biosynthesis of phytochelatin (and other thiol ligands) is also likely to greatly increase the energetic cost in terms of generating reduced carbon.

Vacuolar sequestration provides metal(loid) tolerance by protecting sensitive biochemical machinery in the cytosol but also by preventing translocation of metal(loids) from root to shoot. This is exemplified by studies where the tonoplast $\mathrm{ABCC} 1$ and $\mathrm{ABCC} 2$ were knocked out; mutants showed hypersensitivity to $\mathrm{Cd}$ and $\mathrm{Hg}$ (Park et al., 2012) and, in contrast to WT plants, stored the majority of Cd in the cytoplasm. However, long distance metal translocation was also greater in the mutant (Park et al., 2012).

Alteration of transporters and transport pathways Reducing metal(loid) influx and/or increasing its efflux can both aid in providing tolerance. A significant reduction in AsV uptake can be achieved by manipulating Pi transporters from the Pht family (Shin et al., 2004, Remy et al., 2012) while that of AsIII is greatly lowered by loss of function in NIPs such as Lsi1 (Ma et al., 2008). For Zn, overexpression of the plasma membrane localised OsZIP5 enhanced Zn uptake from the soil which suggests that a loss of function approach could limit Zn toxicity when ambient levels are high (Lee et al., 2010).

Alternatively, one could focus on increasing metal(loid) efflux from the plant. Some members of the ZIP family function as efflux system; Liu et al. (2019) showed that excess $\mathrm{Zn}, \mathrm{Cu}$ and $\mathrm{Cd}$ enhanced the expression level of the plasma membrane localised OsZIP1. Its overexpressing led to better rice growth during metal stress, most likely by functioning as a metal exporter. The finding that metal impact on ZIP1 transcription occurred via the methylating action of a specific histone (H3K9me2) (Liu et al., 2019) provides a potential vehicle for fine-tuning ZIP1 activity. To properly evaluate the efficacy of this system direct evidence for metal efflux, for example by using radio-isotopes, is urgently needed. The use of heterologous systems to enhance efflux is exemplified by expression of the yeast AsIII/ $\mathrm{H}^{+}$antiporter ScACR3p in both Arabidopsis (Ali et al., 2012) and rice (Duan et al., 2012); it successfully increased AsIII efflux from the roots and, in the case of Arabidopsis, improved growth.

Decreasing HMA function could provide avenues to prevent toxic build-up of metal(loid)s in aboveground organs. For example, the presence of metals such as $\mathrm{Cd}$ and $\mathrm{Zn}$ leads to downregulation of HMA4 in the pericycle and was shown to be accompanied by lower accumulation of $\mathrm{Cd}$ and $\mathrm{Zn}$ in leaves of Thlaspi arvense (Hammond et al., 2006), Populus trihocarpa (Hammond et al., 2006, De Oliveira and Tibbett, 2018) and of P. nigra (Adams et al., 2011). Similarly, overexpression in rice of the tonoplast located OsHMA3 (Ueno et al., 2010) greatly enhances Cd sequestration in the root and hence drastically reduced grain Cd levels under field conditions (Lu et al., 2019).

Proteins other than transporters per se, may also be relevant in the endeavour to maximise metal(loid) efflux and reduce translocation to the shoot: loss of function in enzymes involved in biosynthesis of glutathione and phytochelatins in Arabidopsis promoted As efflux from roots. Likewsie, knockout mutations in arsenate reductases such as HAC1 resulted in a reduced ability to efflux AsIII from the roots (Chao et al., 2014) indicating that HAC1 upregulation could enhance this function. Knockout mutations of HAC genes in rice had remarkably similar effects (Shi et al., 2016, Xu et al., 2017).

The problem of transport selectivity Unfortunately, the similarity between metal(loid)s and essential nutrients means many of the above strategies run a considerable risk of negatively affecting plant nutrition. Such a 'cure is worse than the disease' effect is exemplified by the reduced As toxicity in Pi transporter mutants (Shin et al., 2004, Remy et al., 2012). The latter can only thrive if Pi supply is drastically increased. Thus, keeping the "bad metals" out, while allowing the "good ones" in, critically relies on transport selectivity. Theoretically selectivity could be optimised in a number of ways, for instance via selection of appropriate alleles, the implementation of targeted mutations that increase substrate specificity or use of (more selective) heterologous systems. One of the few known examples that illustrate how this benefits plant tolerance is with 
IRT1, a primary Fe transporter localized to the plasma membrane of root rhizodermal cells (Dubeaux et al., 2018). IRT1 functions as a sensor for Fe but reports on excess $\mathrm{Zn}$ and Mn ions in the cytosol. Binding of these non-iron metals to the histidine-rich loop of IRT1 induces its phosphorylation by the CBL-interacting serine/threonine-protein kinase 23 (CIPK23) and subsequent binding to E3 ligase for polyubiquitination and degradation in the vacuole (Dubeaux et al., 2018). In this manner, IRT1 protects the plant from excess metals like $\mathrm{Zn}$ and $\mathrm{Mn}$, whilst safeguarding efficient Fe uptake.

Mutational studies on OsHMA2 identified C-terminal cysteines that impact on metal selectivity (SatohNagasawa et al., 2011). Altered sequences positively impacted on the proportion of $\mathrm{Zn}$ that is translocated to the shoot while limiting the amount of Cd transferred to above ground organs (Satoh-Nagasawa et al., 2011). Cysteines in the C-terminus of another HMA (HMA4) also are likely to impact on selectivity and are involved in Cd transport (Lekeux et al., 2018, Ceasar et al., 2020). Mutations in the histidine-rich loop or in the transmembrane domain of the barley Zn transporter HvMTP1 altered metal specificity by shifting it away from Zn toward Mn and Co (Podar et al., 2012).

The above examples clearly show that there is great scope to optimise transport selectivity in order to discriminate better between toxic and beneficial metal(loid)s

Root morphology/architecture Prolonged exposure to metal(loid)s can alter root cell wall composition. The synthesis and deposition of callose in response to $\mathrm{As}, \mathrm{Cd}$ or $\mathrm{Pb}$ forms a physical barrier that inhibits cell-tocell transport and prevents large scale metal(loid) incursion (Fahr et al., 2013). Similar to callose formation is the accelerated endodermal development in the form of increased suberin deposition and lignification (Lux et al., 2011). In both these cases, creation of a non-specific physical barrier can provide protection against a range of heave metal(loid), including many nutrients. However, such a mechanism may still be beneficial as long a nutrient uptake into the symplast has sufficient selectivity.

Most studies on metal(loid) stress, whether in vitro, hydroponics or compost, are conducted using homogenous distribution of nutrients and contaminants. Yet, natural soils are highly heterogeneous substrates with respect to both chemical and physical components (Hodge, 2009). The heterogeneous distribution of toxic metals under field conditions is exploited by plants by adjusting root architecture in order to avoid contact with contaminants. This 'avoidance response' typically inhibits the primary root growth and stimulates the formation of lateral roots in patches of low metal concentration. Avoidance responses have been observed in several species and for a range of elements, that includes $\mathrm{Ni}, \mathrm{Cd}$, $\mathrm{Zn}$ and $\mathrm{Cu}$ (Remans et al., 2012, Khare et al., 2017, Tognacchini et al., 2020, Palm et al., 2021). A great variability in response is evident across species, subspecies and accessions, and may depend on previous adaptation. For example, Tognacchini et al. (2020) found a much greater Ni-response in a Stellaria media accession that originated in a non-metalliferous soil compared to an accession adapted to ultramafic soil.

Although there may be parallels with more common root tropisms, the metal(loid) sensing and signal pathways that culminate in avoidance responses remain to be discovered. Elegant studies by Khare et al (Khare et al., 2017) using a collection of silenced transcription factor mutants in Arabidopsis, showed that the GPL4 (Glabra1 Enhancer Binding Protein-like 4) transcription factor is involved in the suppression of root growth in areas that contain Cd. Root growth inhibition is likely mediated via generation of ROS that impact on the root apical meristem activity. These authors found that GPL4 not only orchestrated a Cd avoidance response but also suppressed root growth when roots were exposed to essential metals such as $\mathrm{Cu}$ and $\mathrm{Zn}$.

Of course, many non-metal stresses also generate ROS but fail to alter root architecture so the question of response specificity remains unanswered. It would also be very useful to know if and how GPL4 activity integrates into other models that have been advanced such as the localised production of ethylene to decrease lateral root formation (Remans et al., 2012) or the more general role of auxin to sustain root tropisms (Muthert et al., 2020, Lux et al., 2011). Further intriguing issues include the manner in which avoidance responses impact on the acquisition of nutrients and what the signalling components upstream of GPL4 are, particularly the primary sensor(s) that registers initial metal toxicity.

Research into the occurrence of avoidance responses and the opposite behaviour (i.e. active foraging for 
metals which is common in many hyperaccumulators; Tognacchini et al., 2020) has great promise but needs urgent answers to a host of questions: So far it remains unclear whether major crops show avoidance responses, and if so, how relevant they are in overall metal tolerance, particularly with respect to yield. We're also largely ignorant of the genetic basis for this phenomenon and whether this behaviour can be optimised via selection and breeding.

Plant-growth-promoting rhizobacteria/fungi Microbes in the rhizosphere can greatly affect plant growth in a multitude of manners. Bacteria can alter growth through general mechanisms that include synthesising plant growth hormones (i.e. auxin) or compounds that affect plant growth hormones such as ACC (1aminocyclopropane-1-carboxylate) deaminase that reduces the levels ethylene (Wu et al., 2018). Soil bacteria and fungi can usually withstand much higher concentrations of toxic metal(loid)s than plants and therefore are able to proliferate even in highly contaminated soil. This resilience is partly the result of robust export mechanisms to remove pollutants from the cytosol. In addition, microbes may reduce metal availability through specific detoxification pathways that are not found in plants but nevertheless assist plant tolerance. For example, the bacterial Mer operon is responsible for $\mathrm{Hg}$ methylation and subsequent volatilisation that reduces the soil $\mathrm{Hg}$. The Cellulosimicrobium cellulans bacterium can reduce $\mathrm{Cr}^{6+}$ to the non-toxic $\mathrm{Cr}^{3+}$ (Chatterjee et al., 2009) whereas other bacteria can convert AsIII into the far less toxic AsV (e.g. (Majumder et al., 2013).

Microbes can greatly reduce metal(loid) bioavailability through release of chelating exudates and via sorption (Turnau et al., 2012) and thus improve plant growth. Several studies have shown positive effects of (ecto)mycorrhizas to protect trees and plants from heavy metal toxicity particularly by immobilising metals in the extraradical mycelium or hyphal mantle (Krupa and Kozdroj, 2004). Colonisation by arbuscular mycorrhizal fungi (AMF) can also increase plant tolerance by inducing plant genes that are involved in metal detoxification: Rhizophagus irregularis AMF promoted expression of the metallothionein related genePtMT2b in roots of Populus trihocarpa, irrespective of the Cd and Zn concentrations in soil (De Oliveira et al., 2020). Furthermore, AMF reduced the accumulation of $\mathrm{Cd}$ in the leaves by $40 \%$, presumably via its ability to bind $\mathrm{Cd}$ either to the cell wall or intracellularly, thus limiting the $\mathrm{Cd}$ translocation to the shoot.

Soil bacteria with metal tolerance are common amongstPseudomonas, Bacillus, Enterobacter ,Ralstonia and other soil dwelling species. As for fungi, the mitigating effect of bacteria is primarily due to metal(loid) binding to exudates and sorption by cell wall fractions to lower metal(loid) bioavailability.

An in situ study on Lupin (Dary et al., 2010) showed that inoculation with a consortium of metal resistant bacteria generated an increase in plant biomass which was paralleled by a decrease in root and shoot levels of $\mathrm{Cd}, \mathrm{Cu}, \mathrm{Pb}$ and $\mathrm{Zn}$. In contrast, a field study using rape cultivated in contaminated agricultural soil recorded improved growth of the plants in the presence of metal resistant bacteria, but in this case, bacterial activity increased metal bioavailability and hence drastically raised tissue $\mathrm{Cu}$ content (Ren et al., 2019). Some of this contradiction may stem from rape (Brassica napus ) being relatively metal tolerant but it stresses the importance of choosing appropriate rhizosphere organisms that are tailored to specific edaphic conditions and plant hosts.

These examples point to opportunities to exploit soil bacteria and mycorrhization of crops as strategies to aid in their cultivation during metal stress. Where mycorrhizas are concerned, part of the benefits may be via improved nutrition rather than metal detoxification per se, and further studies are needed to tease apart direct and indirect effects. Irrespective of the mechanistic details, we also need far more and better information about the efficacy and (economic) feasibility of manipulating the rhizosphere as an approach to raise plant heavy metal(loid) resistance. Inoculating soils with metal(loid) tolerant bacteria or fungi 'in the field' may be impractical and could be prohibitively expensive. Rhizosphere bacteria may need addition of nutrients to be effective, altering cost-benefit analyses. Alternatively, plants may be selected and/or engineered, to increase microbial activity in the rhizosphere but this is likely to attract a large penalty in reduced carbon and lacks specificity.

\section{SUCCESS STORIES FROM THE FIELD}


For all of the above scenarios there is promising evidence from lab studies. Unfortunately, the latter do often not translate to successes in the field for a plethora of reasons. To assess the efficacy of various approaches we searched the literature to identify work that combines efforts to improve metal(loid) tolerance with crop field trials, for $\mathrm{As}, \mathrm{Cd}, \mathrm{Hg}$ and $\mathrm{Zn}$. Table 1 shows that in general there are very few studies that have evaluated the perceived benefits of lab-based work in the field. Nevertheless, genetic approaches have resulted in some highly successful outcomes: For example, the elegant work by Tang et al. (Tang et al., 2017) used sophisticated CRISPR/Cas genome editing to generate a dysfunctional rice NRAMP5, a plasma membrane transporter that plays an important role in the acquisition of the micronutrient Mn but also contributes to Cd uptake (Ishimaru et al., 2012). Loss of function in NRAMP5 lowered root and shoot levels of $\mathrm{Cd}$ (Figure 4A) and led to a 5 to 30 times reduction in grain Cd levels without a significant yield penalty (an important parameter that is routinely ignored in lab-based studies). The use of CRISPR/Cas allows generation of genetically modified crops that do not contain foreign DNA, thus circumventing problems of public acceptance. Root levels of other essential metals such as $\mathrm{Fe}, \mathrm{Zn}$ and $\mathrm{Cu}$ were not affected by the altered NRAMP activity but the critical role of OsNRAMP5 in Mn nutrition (Ishimaru et al., 2012) means this approach is predicated on sufficient Mn supply. Trials on transgenic rice that overexpressed the sameNRAMP5 showed, as expected, increased root $\mathrm{Cd}$ and $\mathrm{Mn}$ levels (Figure 4B). But the use of strong promoters in this study (OsActin1 and Ubiquitin), altered the expression pattern of NRAMP5, thereby causing a greatly reduced radial transport of $\mathrm{Cd}$ toward the xylem, and surprisingly, this approach also caused a drastic decrease in grain Cd albeit without compromising Mn supply (Chang et al., 2020).

Results from rhizosphere-based approaches are more of a mixed bag; a long term field trial with mycorrhizas revealed no beneficial effects (Gao et al., 2010). Soil amendment with a bacterial mixture (no details are given) lowered bioavailability of $\mathrm{Cd}$ and $\mathrm{Pb}$ in soil but surprisingly, the amendment increased bioavailability of As (Nong et al., 2020). The treatment did not affect plant growth or yield as such but did significantly reduce the level of all three metal(loid)s in the rice grain. The endophytic fungus Piriformospora indica, a regular tobacco symbiont that resides in the roots, caused more efficient storage of $\mathrm{Cd}$ in the roots of colonised plants and, possibly by upregulating genes involved in oxidative stress response, improved tobacco Cd tolerance (Hui et al., 2015).

We could only detect one field study where root architecture was assessed in the context of metal(loid) tolerance (Wu et al., 2011): This report showed that rice genotypes with a relatively high proportion of aerenchyma in their roots (i.e. a high 'porosity') show larger radial oxygen loss and lower As contents in the grain. Maybe the extra oxygen affects the AsIII: AsV ratio but the underlying mechanism remains to be explained.

\section{CONCLUSIONS}

Recent research has revealed many important factors that impinge on plant metal(loid) tolerance. Based on this knowledge, the ideal set of root traits would combine: a low metal(loid) bioavailability, for example by increased organic acid secretion or sorption to rhizosphere bacteria and fungi; limited net influx of metal(loid)s, in particular through enhanced efflux in order not to disrupt nutrient homeostasis; optimised detoxification capacity via vacuolar sequestration in root cells; elevated resilience to counter secondary (oxidative) stress. As yet, most of the above properties only have been examined without regard for important agronomic parameters such as yield. If and how combining all or several of the above will generate synergism is another key factor. Most importantly, we urgently need to scrutinise the efficacy of the above strategies in an agronomically relevant setting; this is currently at best sporadic for approaches such as the manipulation of transport or the role of microbes in the rhizosphere, while totally absent in other cases such as the role of cellular detoxification via metal(loid) liganding and chelation.

\section{References}

ADAMS, J. P., ADELI, A., HSU, C.-Y., HARKESS, R. L., PAGE, G. P., DEPAMPHILIS, C. W., SCHULTZ, E. B. \& YUCEER, C. 2011. Poplar maintains zinc homeostasis with heavy metal genes HMA4 and PCS1. Journal of experimental botany, 62, 3737-3752. 
ALI, W., ISNER, J. C., ISAYENKOV, S. V., LIU, W. J., ZHAO, F. J. \& MAATHUIS, F. J. M. 2012. Heterologous expression of the yeast arsenite efflux system ACR3 improves Arabidopsis thaliana tolerance to arsenic stress. New Phytologist, 194, 716-723.

ARRIVAULT, S., SENGER, T. \& KRAMER, U. 2006. The Arabidopsis metal tolerance protein AtMTP3 maintains metal homeostasis by mediating $\mathrm{Zn}$ exclusion from the shoot under Fe deficiency and Zn oversupply.Plant Journal, 46, 861-879.

ARTZ, J. H., White, S. N., ZADVORNYY, O. A., FUGATE, C. J., HICKS, D., GAUSS, G. H., POSEWITZ, M. C., BOYD, E. S. \& PETERS, J. W. 2015. Biochemical and Structural Properties of a Thermostable Mercuric Ion Reductase from Metallosphaera sedula. Frontiers in Bioengineering and Biotechnology, 3 .

ATDSR, A. F. T. S. A. D. R. 2019. ATSDR's Substance Priority List.In: REGISTRY., A. F. T. S. A. D. (ed.) Available online: www.atsdr.cdc.gov/spl/index.html

ATSDR, A. F. T. S. A. D. R. 1999. Toxicological Profile for Mercury.; Department of Health and Human Services, Public Health Service.Atlanta, GA, USA.

BALI, A. S., SIDHU, G. P. S. \& KUMAR, V. 2020. Root exudates ameliorate cadmium tolerance in plants: A review. Environmental Chemistry Letters, 18, 1243-1275.

BASTA, N. T., RYAN, J. A. \& CHANEY, R. L. 2005. Trace element chemistry in residual-treated soil: key concepts and metal bioavailability.J Environ Qual, 34, 49-63.

BHADURI, A. M. \& FULEKAR, M. H. 2012. Antioxidant enzyme responses of plants to heavy metal stress. Reviews in Environmental Science and Bio-Technology, 11, 55-69.

BUNDSCHUH, M., FILSER, J., LUDERWALD, S., MCKEE, M. S., METREVELI, G., SCHAUMANN, G. E., SCHULZ, R. \& WAGNER, S. 2018. Nanoparticles in the environment: where do we come from, where do we go to? Environ Sci Eur, 30, 6.

CAO, D., CHEN, W., XIANG, Y., MI, Q., LIU, H., FENG, P., SHEN, H., ZHANG, C., WANG, Y. \& WANG, D. 2021. The efficiencies of inorganic mercury bio-methylation by aerobic bacteria under different oxygen concentrations. Ecotoxicology and Environmental Safety,207, 111538.

CARRASCO-GIL, S., ALVAREZ-FERNANDEZ, A., SOBRINO-PLATA, J., MILLAN, R., CARPENARUIZ, R. O., LEDUC, D. L., ANDREWS, J. C., ABADIA, J. \& HERNANDEZ, L. E. 2011. Complexation of $\mathrm{Hg}$ with phytochelatins is important for plant $\mathrm{Hg}$ tolerance. Plant Cell and Environment,34, 778-791.

CARRASCO-GIL, S., SIEBNER, H., LEDUC, D. L., WEBB, S. M., Millan, R., ANDREWS, J. C. \& HERNANDEZ, L. E. 2013. Mercury Localization and Speciation in Plants Grown Hydroponically or in a Natural Environment.Environmental Science ES Technology, 47, 3082-3090.

CATAldO, D. A., GARlAnd, T. R. \& WILDUnG, R. E. 1983. Cadmium Uptake Kinetics in Intact Soybean Plants. Plant Physiology, 73,844-848.

CeAsar, S. A., LeKeuX, G., MOTTe, P., XiAO, Z., GAlleni, M. \& HANIKEnNe, M. 2020. diCysteine Residues of the Arabidopsis thaliana HMA4 C-Terminus Are Only Partially Required for Cadmium Transport.Frontiers in Plant Science, 11.

CHANEY, R. L. 2015. How Does Contamination of Rice Soils with Cd and Zn Cause High Incidence of Human Cd Disease in Subsistence Rice Farmers. Current Pollution Reports, 1, 13-22.

CHANG, J. D., HUANG, S., KONISHI, N., WANG, P., CHEN, J., HUANG, X. Y., MA, J. F. \& ZHAO, F. J. 2020. Overexpression of the manganese/cadmium transporter OsNRAMP5 reduces cadmium accumulation in rice grain. Journal of Experimental Botany, 71, 5705-5715. 
CHAO, D. Y., CHEN, Y., CHEN, J. G., SHI, S. L., CHEN, Z. R., WANG, C. C., DANKU, J. M., ZHAO, F. J. \& SALT, D. E. 2014. Genome-wide Association Mapping Identifies a New Arsenate Reductase Enzyme Critical for Limiting Arsenic Accumulation in Plants. Plos Biology, 12.

CHAO, D. Y., SILVA, A., BAXTER, I., HUANG, Y. S., NORDBORG, M., DANKU, J., LAHNER, B., YAKUBOVA, E. \& SALT, D. E. 2012. Genome-Wide Association Studies Identify Heavy Metal ATPase3 as the Primary Determinant of Natural Variation in Leaf Cadmium in Arabidopsis thaliana. Plos Genetics, 8.

CHATTERJEe, S., SAU, G. B. \& MUKHERJEE, S. K. 2009. Plant growth promotion by a hexavalent chromium reducing bacterial strain, Cellulosimicrobium cellulans KUCr3. World Journal of Microbiology $\&$ Biotechnology, 25, 1829-1836.

CHEN, B. D., NAYUKI, K., KUGA, Y., ZHANG, X., WU, S. L. \& OHTOMO, R. 2018. Uptake and Intraradical Immobilization of Cadmium by Arbuscular Mycorrhizal Fungi as Revealed by a Stable Isotope Tracer and Synchrotron Radiation mu X-Ray Fluorescence Analysis. Microbes and Environments, 33, 257263.

CHIARUCCI, A. \& BAKER, A. J. M. 2007. Advances in the ecology of serpentine soils. Plant and Soil, 293, 1-2.

CLEMENS, S. 2019. Metal ligands in micronutrient acquisition and homeostasis. Plant Cell and Environment, 42, 2902-2912.

CLEMENS, S. \& MA, J. F. 2016. Toxic Heavy Metal and Metalloid Accumulation in Crop Plants and Foods. Annual Review of Plant Biology, Vol 67, 67, 489-512.

COCCINA, A., CAVAGNARO, T. R., PELlEGRINO, E., ERCOLI, L., MClAUGHLIN, M. J. \& WATTSWILLIAMS, S. J. 2019. The mycorrhizal pathway of zinc uptake contributes to zinc accumulation in barley and wheat grain.BMC Plant Biology, 19, 133.

DARY, M., ChAmBER-PEREZ, M. A., PAlOMARES, A. J. \& PAJUElO, E. 2010. "In situ" phytostabilisation of heavy metal polluted soils using Lupinus luteus inoculated with metal resistant plant-growth promoting rhizobacteria. Journal of Hazardous Materials, 177,323-330.

DE OLIVEIRA, V. H. \& TIBBETT, M. 2018. Tolerance, toxicity and transport of Cd and Zn in Populus trichocarpa. Environmental and Experimental Botany, 155, 281-292.

DE OLIVEIRA, V. H., ULLAH, I., DUNWELL, J. M. \& TIBBETT, M. 2020. Mycorrhizal symbiosis induces divergent patterns of transport and partitioning of $\mathrm{Cd}$ and $\mathrm{Zn}$ in Populus trichocarpa. Environmental and Experimental Botany, 171, 103925.

DUAN, G. L., KAMIYA, T., ISHIKAWA, S., ARAO, T. \& FUJIWARA, T. 2012. Expressing ScACR3 in Rice Enhanced Arsenite Efflux and Reduced Arsenic Accumulation in Rice Grains. Plant and Cell Physiology,53, 154-163.

DUBEAUX, G., NEVEU, J., ZELAZNY, E. \& VERT, G. 2018. Metal Sensing by the IRT1 TransporterReceptor Orchestrates Its Own Degradation and Plant Metal Nutrition. Molecular Cell, 69, 953-+.

ERENOGLU, B., EKER, S., CAKMAK, I., DERICI, R. \& ROMHELD, V. 2000. Effect of iron and zinc deficiency on release of phytosiderophores in barley cultivars differing in zinc efficiency. Journal of Plant Nutrition, 23, 1645-1656.

FAHR, M., LAPLAZE, L., BENDAOU, N., HOCHER, V., EL MZIBRI, M., BOGUSZ, D. \& SMOUNI, A. 2013. Effect of lead on root growth. Frontiers in Plant Science, 4.

FAO, T. S. O. F. I. I. T. W. 2015.

FENG, S. S., TAN, J. J., ZHANG, Y. X., LIANG, S., XIANG, S. Q., WANG, H. \& CHAI, T. Y. 2017. Isolation and characterization of a novel cadmium-regulated Yellow Stripe-Like transporter (SnYSL3) in 
Solanum nigrum. Plant Cell Reports, 36, 281-296.

FONTANILI, L., LANCILLI, C., SUZUI, N., DENDENA, B., YIN, Y.-G., FERRI, A., ISHII, S., KAWACHI, N., LUCChINI, G., FUJIMAKI, S., SACCHI, G. A. \& NOCITO, F. F. 2016. Kinetic Analysis of Zinc/Cadmium Reciprocal Competitions Suggests a Possible Zn-Insensitive Pathway for Root-to-Shoot Cadmium Translocation in Rice. Rice, 9,16.

FRAUSTO DA SILVA JJR, W. R. 2001. The biological chemistry of the elements: the inorganic chemistry of life, New York, Oxford University Press.

GAO, X., AKHTER, F., TenutA, M., Flaten, D. N., GAWAlKO, E. J. \& GRANT, C. A. 2010. Mycorrhizal colonization and grain Cd concentration of field-grown durum wheat in response to tillage, preceding crop and phosphorus fertilization. J Sci Food Agric, 90, 750-8.

GREGER, M., KABIR, A. H., LANDBERG, T., MAITY, P. J. \& LINDBERG, S. 2016. Silicate reduces cadmium uptake into cells of wheat.Environmental Pollution, 211, 90-97.

GUO, B., LIU, C., DING, N. F., FU, Q. L., LIN, Y. C., LI, H. \& LI, N. Y. 2016. Silicon Alleviates Cadmium Toxicity in Two Cypress Varieties by Strengthening the Exodermis Tissues and Stimulating Phenolic Exudation of Roots. Journal of Plant Growth Regulation, 35,420-429.

GUSTin, J. L., LOUREIRO, M. E., KIM, D., NA, G., TIKHONOVA, M. \& SALT, D. E. 2009. MTP1dependent Zn sequestration into shoot vacuoles suggests dual roles in Zn tolerance and accumulation in Zn-hyperaccumulating plants. Plant Journal, 57, 1116-1127.

GWOREK, B., DMUCHOWSKI, W. \& BACZEWSKA-DABROWSKA, A. H. 2020. Mercury in the terrestrial environment: a review. Environmental Sciences Europe, 32, 128.

HAMMOND, J. P., BOWEN, H. C., WHITE, P. J., MILlS, V., PYKE, K. A., BAKER, A. J., WHITING, S. N., MAY, S. T. \& BROADLEY, M. R. 2006. A comparison of the Thlaspi caerulescens and Thlaspi arvense shoot transcriptomes. New Phytol, 170, 239-60.

HANIKENNE, M., TALKE, I. N., HAYDON, M. J., LANZ, C., NOLTE, A., MOTTE, P., KROYMANN, J., WEIGEL, D. \& KRAMER, U. 2008. Evolution of metal hyperaccumulation required cis-regulatory changes and triplication of HMA4. Nature, 453, 391-U44.

HAYAT, S., HAYAT, Q., AlYEMEnI, M. N., WANI, A. S., PICHTEL, J. \& AHMAD, A. 2012. Role of proline under changing environments: a review.Plant Signal Behav, 7, 1456-66.

HAYDON, M. J. \& COBBETT, C. S. 2007. Transporters of ligands for essential metal ions in plants. New Phytologist, 174,499-506.

HODGE, A. 2009. Root decisions. Plant Cell Environ, 32,628-40.

HU, M., LI, F. B., LIU, C. P. \& WU, W. J. 2015. The diversity and abundance of As(III) oxidizers on root iron plaque is critical for arsenic bioavailability to rice. Scientific Reports, 5 .

HUI, F. Q., LIU, J., GAO, Q. K. \& LOU, B. G. 2015. Piriformospora indica confers cadmium tolerance in Nicotiana tabacum. Journal of Environmental Sciences, 37, 184-191.

ISHIMARU, Y., TAKAHASHI, R., BASHIR, K., SHIMO, H., SENOURA, T., SUGIMOTO, K., ONO, K., YANO, M., ISHIKAWA, S., ARAO, T., NAKANISHI, H. \& NISHIZAWA, N. K. 2012. Characterizing the role of rice NRAMP5 in Manganese, Iron and Cadmium Transport. Scientific Reports, 2.

JAIN, A., SINILAL, B., DHANDAPANI, G., MEAGHER, R. B. \& SAHI, S. V. 2013. Effects of Deficiency and Excess of Zinc on Morphophysiological Traits and Spatiotemporal Regulation of Zinc-Responsive Genes Reveal Incidence of Cross Talk between Micro- and Macronutrients.Environmental Science \& Technology, $47,5327-5335$.

JEONG, J. \& EIDE, D. J. 2013. The SLC39 family of zinc transporters.Mol Aspects Med, 34, 612-9. 
KAMBE, T., TSUJI, T., HASHIMOTO, A. \& ITSUMURA, N. 2015. The Physiological, Biochemical, and Molecular Roles of Zinc Transporters in Zinc Homeostasis and Metabolism. Physiol Rev, 95,749-84.

KELlER, C., MCGRATH, S. P. \& DUNHAM, S. J. 2002. Trace metal leaching through a soil-grassland system after sewage sludge application. J Environ Qual, 31, 1550-60.

KHARE, D., MiTSUDA, N., LEE, S., SONG, W. Y., HWANG, D., OHME-TAKAGI, M., MARTINOIA, E., LEE, Y. \& HWANG, J. U. 2017. Root avoidance of toxic metals requires the GeBP-LIKE 4 transcription factor in Arabidopsis thaliana. New Phytologist, 213, 1257-1273.

KOTECHA, M., MEDHAVI, CHAUDHARY, S., MARWA, N., DEEBA, F., PANDEY, V. \& PRASAD, V. 2019. Metals, Crops and Agricultural Productivity: Impact of Metals on Crop Loss. In: SRIVASTAVA, S., SRIVASTAVA, A. K. \& SUPRASANNA, P. (eds.) Plant-Metal Interactions. Cham: Springer International Publishing.

KOzhevnikova, A. D., Seregin, I. V., ERLikH, N. T., SheVyreva, T. A., Andreev, I. M., VERWEIJ, R. \& SCHAT, H. 2014a. Histidine-mediated xylem loading of zinc is a species-wide character in Noccaea caerulescens. New Phytol, 203, 508-519.

KOZHEVNIKOVA, A. D., SEREGIN, I. V., VERWEIJ, R. \& SCHAT, H. 2014b. Histidine promotes the loading of nickel and zinc, but not of cadmium, into the xylem in Noccaea caerulescens. Plant Signal Behav,9, e29580.

KRISHNA, A. T. P., MAHARAJAN, T., VICTOR ROCH, G., IGNACIMUTHU, S. \& ANTONY CEASAR, S. 2020. Structure, Function, Regulation and Phylogenetic Relationship of ZIP Family Transporters of Plants. Frontiers in Plant Science, 11.

KRUPA, P. \& KOZDROJ, J. 2004. Accumulation of heavy metals by ectomycorrhizal fungi colonizing birch trees growing in an industrial desert soil. World Journal of Microbiology $\&$ Biotechnology,20, 427-430.

KUMARI, S., AMIT, JAMWAL, R., MISHRA, N. \& SINGH, D. K. 2020. Recent developments in environmental mercury bioremediation and its toxicity: A review. Environmental Nanotechnology, Monitoring $\mathcal{E}$ Management,13, 100283.

LEE, S., JEONG, H. J., KIM, S. A., LEE, J., GUERINOT, M. L. \& AN, G. 2010. OsZIP5 is a plasma membrane zinc transporter in rice. Plant Mol Biol, 73, 507-17.

LEKEUX, G., LAURENT, C., JORIS, M., JADOUL, A., JiANG, D., BOSMAN, B., CARNOL, M., MOTTE, P., XIAO, Z., GALLENI, M. \& HANIKENNE, M. 2018. di-Cysteine motifs in the C-terminus of plant HMA4 proteins confer nanomolar affinity for zinc and are essential for HMA4 function in vivo.Journal of Experimental Botany, 69, 5547-5560.

LETERME, B., BLANC, P. \& JACQUES, D. 2014. A reactive transport model for mercury fate in soilapplication to different anthropogenic pollution sources. Environmental Science and Pollution Research,21, 12279-12293.

LI, D., XU, X., HU, X., LIU, Q., WANG, Z., ZHANG, H., WANG, H., WEI, M., WANG, H., LIU, H. \& LI, C. 2015. Genome-Wide Analysis and Heavy Metal-Induced Expression Profiling of the HMA Gene Family in Populus trichocarpa. Frontiers in plant science, 6, 1149-1149.

LI, J., SUN, Y., JIANG, X., CHEN, B. \& ZHANG, X. 2018. Arbuscular mycorrhizal fungi alleviate arsenic toxicity to Medicago sativa by influencing arsenic speciation and partitioning. Ecotoxicol Environ Saf, 157, 235-243.

LI, Y. J., DHANKHER, O. P., CARREIRA, L., LEE, D., CHEN, A., SCHROEDER, J. I., BALISH, R. S. \& MEAGHER, R. B. 2004. Overexpression of phytochelatin synthase in Arabidopsis leads to enhanced arsenic tolerance and cadmium hypersensitivity. Plant and Cell Physiology, 45, 1787-1797. 
LilAy, G. H., PERSSON, D. P., CASTRO, P. H., LiAO, F., AlEXANDER, R. D., AARTS, M. G. M. \& ASSUNÇÃO, A. G. L. 2021. Arabidopsis bZIP19 and bZIP23 act as zinc sensors to control plant zinc status. Nature plants, 7, 137-143.

LINDSAY, E. R. \& MAATHUIS, F. J. M. 2016. Arabidopsis thaliana NIP7;1 is involved in tissue arsenic distribution and tolerance in response to arsenate. Febs Letters, 590, 779-786.

LINDSAY, E. R. \& MAATHUIS, F. J. M. 2017. New Molecular Mechanisms to Reduce Arsenic in Crops. Trends in Plant Science, 22,1016-1026.

LIU, X. S., FENG, S. J., ZHANG, B. Q., WANG, M. Q., CAO, H. W., RONO, J. K., CHEN, X. \& YANG, Z. M. 2019. OsZIP1 functions as a metal efflux transporter limiting excess zinc, copper and cadmium accumulation in rice. Bmc Plant Biology, 19.

LÓPEZ-MILlÁN, A.-F., ELLIS, D. R. \& GRUSAK, M. A. 2004. Identification and Characterization of Several New Members of the ZIP Family of Metal Ion Transporters in Medicago Truncatula. Plant Molecular Biology,54, 583-596.

LU, C., ZHANG, L., TANG, Z., HUANG, X.-Y., MA, J. F. \& ZHAO, F.-J. 2019. Producing cadmium-free Indica rice by overexpressing OsHMA3.Environment International, 126, 619-626.

LUX, A., MARTINKA, M., VACULIK, M. \& WHITE, P. J. 2011. Root responses to cadmium in the rhizosphere: a review. Journal of Experimental Botany, 62, 21-37.

MA, J. F., YAMAJI, N., MITANI, N., XU, X. Y., SU, Y. H., MCGRATH, S. P. \& ZHAO, F. J. 2008. Transporters of arsenite in rice and their role in arsenic accumulation in rice grain. Proceedings of the National Academy of Sciences of the United States of America, 105,9931-9935.

MA, M., DU, H. \& WANG, D. 2019. Mercury methylation by anaerobic microorganisms: A review. Critical Reviews in Environmental Science and Technology, 49, 1893-1936.

MAISCH, M., LUEDER, U., KAPPLER, A. \& SCHMIDT, C. 2020. From Plant to Paddy-How Rice Root Iron Plaque Can Affect the Paddy Field Iron Cycling.Soil Systems, 4.

MAJUMDER, A., BHATTACHARYYA, K., BHATTACHARYYA, S. \& KOLE, S. C. 2013. Arsenic-tolerant, arsenite-oxidising bacterial strains in the contaminated soils of West Bengal, India. Science of the Total Environment, 463, 1006-1014.

MARSCHNER, P. 2012. Mineral Nutrition of Higher Plants, Academic Press.

MCLAUGHLin, M. J., HAMON, R. E., MCLAREN, R. G., SPEIR, T. W. \& ROGERS, S. L. 2000. Review: A bioavailability-based rationale for controlling metal and metalloid contamination of agricultural land in Australia and New Zealand. Soil Research, 38, 1037-1086.

MEHARG, A. A. \& RAHMAN, M. 2003. Arsenic contamination of Bangladesh paddy field soils: Implications for rice contribution to arsenic consumption. Environmental Science $\mathcal{E}$ Technology, 37,229-234.

MIGEON, A., BLAUDEZ, D., WILKINS, O., MONTANINI, B., CAMPBELL, M. M., RICHAUD, P., THOMINE, S. \& CHALOT, M. 2010. Genome-wide analysis of plant metal transporters, with an emphasis on poplar. Cellular and Molecular Life Sciences, 67, 3763-3784.

MILNER, M. J., SEAMON, J., CRAFT, E. \& KOCHIAN, L. V. 2013. Transport properties of members of the ZIP family in plants and their role in Zn and Mn homeostasis. Journal of Experimental Botany, $64,369-381$.

Morel, M., Crouzet, J., Gravot, A., Auroy, P., LEONHARDT, N., VAVASSEuR, A. \& RICHAUD, P. 2009. AtHMA3, a P1B-ATPase allowing Cd/Zn/Co/Pb vacuolar storage in Arabidopsis. Plant Physiol, 149,894-904. 
MOSA, K. A., KUMAR, K., CHHIKARA, S., MCDERMOTT, J., LIU, Z. J., MUSANTE, C., White, J. C. \& DHANKHER, O. P. 2012. Members of rice plasma membrane intrinsic proteins subfamily are involved in arsenite permeability and tolerance in plants. Transgenic Research,21, 1265-1277.

MUTHERT, L. W. F., IZZO, L. G., VAN ZANTEN, M. \& ARONNE, G. 2020. Root Tropisms: Investigations on Earth and in Space to Unravel Plant Growth Direction. Frontiers in Plant Science, 10.

NAIR, A., JUWARKAR, A. A. \& SINGH, S. K. 2007. Production and characterization of siderophores and its application in arsenic removal from contaminated soil. Water Air and Soil Pollution,180, 199-212.

NOCTOR, G., MHAMDI, A. \& FOYER, C. H. 2016. Oxidative stress and antioxidative systems: recipes for successful data collection and interpretation. Plant Cell and Environment, 39,1140-1160.

NONG, X. Y., ZHANG, C. L., CHEN, H. X., RONG, Q., GAO, H. F. \& JIN, X. D. 2020. Remediation of $\mathrm{Cd}, \mathrm{Pb}$ and as Co-contaminated Paddy Soil by Applying Different Amendments. Bulletin of Environmental Contamination and Toxicology, 105, 283-290.

ORTEGA-VILlasAnte, C., RELlÁN-ALVAREZ, R., DEL CAMPO, F. F., CARPENA-RUiz, R. O. \& HERNÁNDEZ, L. E. 2005. Cellular damage induced by cadmium and mercury in Medicago sativa. J Exp Bot, 56,2239-51.

PALM, E., GUIDI NISSIM, W., MANCUSO, S. \& AZZARELLO, E. 2021. Split-root investigation of the physiological response to heterogeneous elevated Zn exposure in poplar and willow. Environmental and Experimental Botany, 183, 104347.

PARK, J., SONG, W. Y., KO, D., EOM, Y., HANSEN, T. H., SCHILLER, M., LEE, T. G., MARTINOIA, E. \& LEE, Y. 2012. The phytochelatin transporters AtABCC1 and AtABCC2 mediate tolerance to cadmium and mercury. Plant Journal, 69, 278-288.

PEREZ; A. P. \& EUGENIO, N. R. 2018. Status of local soil contamination in Europe: Revision of the indicator "Progress in the management contaminated sites in Europe". Luxembourg,.

PINTO, A. P., SIMOES, I. \& MOTA, A. M. 2008. Cadmium impact on root exudates of sorghum and maize plants: A speciation study. Journal of Plant Nutrition, 31, 1746-1755.

PODAR, D., SCHERER, J., NOORDALLY, Z., HERZYK, P., NIES, D. \& SANDERS, D. 2012. Metal selectivity determinants in a family of transition metal transporters. J Biol Chem, 287, 3185-96.

PRASAD, A. S. 2014. Impact of the discovery of human zinc deficiency on health. J Trace Elem Med Biol, $28,357-63$.

RAJ, D. \& MAITI, S. K. 2019. Sources, toxicity, and remediation of mercury: an essence review. Environmental Monitoring and Assessment, 191, 566.

REMANS, T., THIJS, S., TRUYENS, S., WEYENS, N., SCHELlingEN, K., KEUNEN, E., GIELEN, H., CUYPERS, A. \& VANGRONSVELD, J. 2012. Understanding the development of roots exposed to contaminants and the potential of plant-associated bacteria for optimization of growth. Ann Bot,110, 23952.

REMY, E., CABRITO, T. R., BATISTA, R. A., TEIXEIRA, M. C., SA-CORREIA, I. \& DUQUE, P. 2012. The Pht 1;9 and Pht1;8 transporters mediate inorganic phosphate acquisition by the Arabidopsis thaliana root during phosphorus starvation. New Phytol, 195, 356-371.

REN, X. M., GUO, S. J., TIAN, W., CHEN, Y., HAN, H., CHEN, E., LI, B. L., LI, Y. Y. \& CHEN, Z. J. 2019. Effects of Plant Growth-Promoting Bacteria (PGPB) Inoculation on the Growth, Antioxidant Activity, $\mathrm{Cu}$ Uptake, and Bacterial Community Structure of Rape (Brassica napus L.) Grown in Cu-Contaminated Agricultural Soil. Frontiers in Microbiology, 10. 
RENU, K., CHAKRABORTY, R., MYAKAlA, H., KOTI, R., FAMUREWA, A. C., MADHYASTHA, H., VELLINGIRI, B., GEORGE, A. \& VALSALA GOPALAKRISHNAN, A. 2021. Molecular mechanism of heavy metals (Lead, Chromium, Arsenic, Mercury, Nickel and Cadmium) - induced hepatotoxicity - A review. Chemosphere, 271, 129735.

RIDDLE, S. G., TRAN, H. H., DEWITT, J. G. \& ANDREWS, J. C. 2002. Field, laboratory, and X-ray absorption spectroscopic studies of mercury accumulation by water hyacinths. Environ Sci Technol,36, 196570.

ROSENZWEIG, A. C. 2002. Metallochaperones: bind and deliver. Chem Biol, 9, 673-7.

SATOH-NAGASAWA, N., MORI, M., NAKAZAWA, N., KAWAMOTO, T., NAGATO, Y., SAKURAI, K., TAKAHASHI, H., WATANABE, A. \& AKAGI, H. 2011. Mutations in Rice (Oryza sativa) Heavy Metal ATPase 2 (OsHMA2) Restrict the Translocation of Zinc and Cadmium. Plant and Cell Physiology,53, 213224.

SCHWESIG, D. \& KREBS, O. 2003. The role of ground vegetation in the uptake of mercury and methylmercury in a forest ecosystem. Plant and Soil, 253, 445-455.

SHI, S., WANG, T., CHEN, Z., TANG, Z., WU, Z., SALT, D. E., CHAO, D. Y. \& ZHAO, F. J. 2016. OsHAC1;1 and OsHAC1;2 Function as Arsenate Reductases and Regulate Arsenic Accumulation. Plant Physiol,172, 1708-1719.

SHIM, D., HWANG, J. U., LEE, J., LEE, S., CHOI, Y., AN, G., MARTINOIA, E. \& LEE, Y. 2009. Orthologs of the class A4 heat shock transcription factor HsfA4a confer cadmium tolerance in wheat and rice. Plant Cell, 21, 4031-43.

SHIN, H., SHIN, H. S., DEWBRE, G. R. \& HARRISON, M. J. 2004. Phosphate transport in Arabidopsis: Pht1;1 and Pht1;4 play a major role in phosphate acquisition from both low- and high-phosphate environments.Plant $J, 39,629-42$.

SILVER, S. A. \& HOBMAN, J. L. 2007. Mercury Microbiology: Resistance Systems, Environmental Aspects, Methylation, and Human Health, Berlin, Heidelberg, Springer.

SINGH, S., TRIPATHI, D. K., CHAUHAN, D. K. \& DUBEY, N. K. 2016. Glutathione and Phytochelatins Mediated Redox Homeostasis and Stress Signal Transduction in Plants: An Integrated Overview. Plant Metal Interaction: Emerging Remediation Techniques , 285-310.

SONG, W.-Y., YAMAKI, T., YAMAJI, N., KO, D., JUNG, K.-H., FUJII-KASHINO, M., AN, G., MARTINOIA, E., LEE, Y. \& MA, J. F. 2014. A rice ABC transporter, OsABCC1, reduces arsenic accumulation in the grain.Proceedings of the National Academy of Sciences, 111,15699-15704.

SONG, Y., JIN, L. \& WANG, X. J. 2017. Cadmium absorption and transportation pathways in plants. International Journal of Phytoremediation, 19, 133-141.

SPAGNOlETti, F. N., BALESTRASSE, K., LAVADO, R. S. \& GIACOMETTI, R. 2016. Arbuscular mycorrhiza detoxifying response against arsenic and pathogenic fungus in soybean. Ecotoxicology and Environmental Safety, 133, 47-56.

SUZUKI, M., TAKAHASHI, M., TSUKAMOTO, T., WATANABE, S., MATSUHASHI, S., YAZAKI, J., KISHIMOTO, N., KIKUCHI, S., NAKANISHI, H., MORI, S. \& NISHIZAWA, N. K. 2006. Biosynthesis and secretion of mugineic acid family phytosiderophores in zinc-deficient barley. Plant J,48, 85-97.

TANAKA, N., KAWACHI, M., FUJIWARA, T. \& MAESHIMA, M. 2013. Zinc-binding and structural properties of the histidine-rich loop of Arabidopsis thaliana vacuolar membrane zinc transporter MTP1. FEBS Open Bio,3, 218-24.

TANG, L., MAO, B., LI, Y., LV, Q., ZHANG, L., CHEN, C., HE, H., WANG, W., ZENG, X., SHAO, Y., PAN, Y., HU, Y., PENG, Y., FU, X., LI, H., XIA, S. \& ZHAO, B. 2017. Knockout of OsNRAMP5 using 
the CRISPR/Cas9 system produces low Cd-accumulating indica rice without compromising yield.Sci Rep, 7,14438 .

TASHAKOR, M., YAACOB, W. Z. W. \& MOHAMAD, H. 2013. Serpentine Soils, Adverse Habitat for Plants. American Journal of Environmental Sciences, 9.

ThORNE, S. J., HARTlEy, S. E. \& MAATHuis, F. J. M. 2020. Is Silicon a Panacea for Alleviating Drought and Salt Stress in Crops? Frontiers in plant science, 11, 1221-1221.

TOGNACCHINI, A., SALINITRO, M., PUSCHENREITER, M. \& VAN DER ENT, A. 2020. Root foraging and avoidance in hyperaccumulator and excluder plants: a rhizotron experiment. Plant and Soil, 450,287-302.

TÓTH, G., HERMANN, T., DA SILVA, M. R. \& MONTANARELLA, L. 2016. Heavy metals in agricultural soils of the European Union with implications for food safety. Environment International, 88, 299-309.

TRIPATHI, R. D., SRIVASTAVA, S., MISHRA, S., SINGH, N., TUli, R., GUPTA, D. K. \& MAATHUIS, F. J. 2007. Arsenic hazards: strategies for tolerance and remediation by plants. Trends Biotechnol, 25,158-65.

TURNAU, K., GAWROŃSKI, S., RYSZKA, P. \& ZOOK, D. 2012. Mycorrhizal-Based Phytostabilization of $\mathrm{Zn}-\mathrm{Pb}$ Tailings: Lessons from the Trzebionka Mining Works (Southern Poland). In: KOTHE, E. \& VARMA, A. (eds.) Bio-Geo Interactions in Metal-Contaminated Soils. Berlin, Heidelberg: Springer Berlin Heidelberg.

UENO, D., YAMAJI, N., KONO, I., HUANG, C. F., ANDO, T., YANO, M. \& MA, J. F. 2010. Gene limiting cadmium accumulation in rice. Proc Natl Acad Sci U S A, 107, 16500-5.

USEPA; UNITED STATES ENVIRONMENTAL PROTECTION AGENCY 2007. Treatment Technologies for Mercury in Soil, Waste, and Water.

VALLEE, B. L. A. \& ULMER, D. D. 1972. Biochemical Effects of Mercury, Cadmium, and Lead. Annual Review of Biochemistry, 41,91-128.

VERRET, F., GRAVOT, A., AUROY, P., LEONhARDT, N., DAVID, P., NUSSAUME, L., VAVASSEUR, A. \& RICHAUD, P. 2004. Overexpression of AtHMA4 enhances root-to-shoot translocation of zinc and cadmium and plant metal tolerance. FEBS Letters, 576, 306-312.

VON WIREN, N., MARSCHNER, H. \& ROMHELD, V. 1996. Roots of Iron-Efficient Maize also Absorb Phytosiderophore-Chelated Zinc. Plant Physiology, 111, 1119-1125.

WATtS-Williams, S. J., SMith, F. A., MClaughlin, M. J., PATti, A. F. \& CAVAGnaro, T. R. 2015. How important is the mycorrhizal pathway for plant Zn uptake? Plant and Soil, 390, 157-166.

WHITING, S. N., LEAKE, J. R., MCGRATH, S. P. \& BAKER, A. J. M. 2000. Positive responses to Zn and Cd by roots of the Zn and Cd hyperaccumulator Thlaspi caerulescens. New Phytologist,145, 199-210.

WHO, W. H. O. 2013. Research for universal health coverage.

WILSON, N. 2018. Nanoparticles: Environmental Problems or Problem Solvers? BioScience, 68, 241-246.

WONG, C. K. E., JARVIS, R. S., SHERSON, S. M. \& COBBETT, C. S. 2009. Functional analysis of the heavy metal binding domains of the $\mathrm{Zn} / \mathrm{Cd}$-transporting ATPase, HMA2, in Arabidopsis thaliana. New Phytologist, 181, 79-88.

WU, C., YE, Z., SHU, W., ZHU, Y. \& WONG, M. 2011. Arsenic accumulation and speciation in rice are affected by root aeration and variation of genotypes. Journal of Experimental Botany, 62,2889-2898.

WU, L., LI, X., MA, L., BORRISS, R., WU, Z. \& GAO, X. 2018. Acetoin and 2,3-butanediol from Bacillus amyloliquefaciens induce stomatal closure in Arabidopsis thaliana and Nicotiana benthamiana. Journal of Experimental Botany, 69, 5625-5635. 
WUANA, R. A. \& OKIEIMEN, F. E. 2011. Heavy Metals in Contaminated Soils: A Review of Sources, Chemistry, Risks and Best Available Strategies for Remediation. ISRN Ecology, 2011, 402647.

XU, J., SHI, S., WANG, L., TANG, Z., LV, T., ZHU, X., DING, X., WANG, Y., ZHAO, F.-J. \& WU, Z. 2017. OsHAC4 is critical for arsenate tolerance and regulates arsenic accumulation in rice. New Phytologist, 215, 1090-1101.

YU, H. Y., WANG, X. Q., LI, F. B., LI, B., LIU, C. P., WANG, Q. \& LEI, J. 2017. Arsenic mobility and bioavailability in paddy soil under iron compound amendments at different growth stages of rice.Environmental Pollution, 224, 136-147.

ZANElla, L., FATtORIni, L., BRUNetTi, P., ROCCOTIEllo, E., CORNARA, L., D'ANGELI, S., DELlA ROVERE, F., CARDARELLI, M., BARBIERI, M., SANITA DI TOPPI, L., DEGOLA, F., LINDBERG, S., ALTAMURA, M. M. \& FALASCA, G. 2016. Overexpression of AtPCS1 in tobacco increases arsenic and arsenic plus cadmium accumulation and detoxification. Planta,243, 605-622.

ZHANG, J., MARTINOIA, E. \& LEE, Y. 2018. Vacuolar Transporters for Cadmium and Arsenic in Plants and their Applications in Phytoremediation and Crop Development. Plant and Cell Physiology, 59,13171325 .

ZHANG, T., KULIYEV, E., SUI, D. \& HU, J. 2019. The histidine-rich loop in the extracellular domain of ZIP4 binds zinc and plays a role in zinc transport. The Biochemical journal, 476, 1791-1803.

ZHAO, F. J., MA, J. F., MEHARG, A. A. \& MCGRATH, S. P. 2009. Arsenic uptake and metabolism in plants. New Phytologist, 181,777-794.

ZHOU, Z. S., HUANG, S. Q., GUO, K., MEHTA, S. K., ZHANG, P. C. \& YANG, Z. M. 2007. Metabolic adaptations to mercury-induced oxidative stress in roots of Medicago sativa L. Journal of Inorganic Biochemistry,101, 1-9.

Figure legends

Figure 1: Generic, root and rhizosphere located processes that contribute to plant metal(loid) tolerance.

See text for details.

Figure 2: Overview of root and rhizosphere located response mechanisms to metal(loid) toxicity. 1) The uptake, efflux and long distance transport of metal(loid)s critically influences metal(loid) tolerance. The contributing transport steps, which may be controlled by transcriptional and post- transcriptional mechanisms, determine the partitioning of metal(loid)s within cells and in different organs. 2) Detoxification within the cells often depends on metal(loid) conjugation to thiol rich compounds and subsequent sequestration in the vacuole via specific transporters on the tonoplast. 3) Root architecture adapts to metal(loid) toxicity for example via reduced root growth ('avoidance response') or the formation of physical barriers in root tissues by deposition of callose, suberin or lignin. 4) The presence of bacteria and fungi in the rhizosphere impacts on metal(loid) bioavailability via the chelating activity of microbial exudates (PGP compounds). Microbes can also be involved in the bioconversion of metal(loid)s, for example via redox reactions or methylation. 5) Like microbial exudates, plant exudates such as organic acids and phytosiderophores can impact on metal(loid) solubility and bioavailability. Abbreviations: GSH: reduced glutathione; PC: phytochelatins; PGP: plant growth promoting ; TO: tonoplast; PM: plasma membrane; Me: Metal(loid).

Figure 3: Uptake and detoxification of $\mathbf{A s}, \mathbf{C d}, \mathbf{H g}$ and $\mathbf{Z n}$. The uptake of As, $\mathrm{Cd}, \mathrm{Hg}$ and $\mathrm{Zn}$ is largely catalysed by transporters that reside in the plasma membrane (PM) and derive from various families. Very often, selectivity is not perfect which leads to substrate interactions such as As affecting uptake of $\mathrm{Si}$ and phosphate $(\mathrm{Pi})$ and $\mathrm{Cd}$ interference with $\mathrm{Fe}, \mathrm{Zn}$ and $\mathrm{Mn}$ nutrition. High affinity thiol groups of reducing compounds such as glutathione (GSH) and phytochelatin (PC) catalyse binding of metal(loid)s for delivery to the vacuolar lumen, neutralising much of the potential toxicity. Transport of the complexed metals into 
the vacuole (Vac) mainly relies on the activity of ABC transporters and heavy metal ATPases expressed on the tonoplast (TO). Abbreviations: GSH: reduced glutathione; PC: phytochelatins; PGP: plant growth promoting ; TO: tonoplast; PM: plasma membrane; Pi: inorganic phosphate. For abbreviations of specific transporters, see text.

Figure 4: Altering NRAMP expression lowers Cd in rice grain. The physiological function of OsNRAMP5 is in the acquisition of the micronutrient Mn, however, NRAMP5 can also mediate Cd uptake. In wild-type (WT) plants, NRAMP5 is expressed on the distal side of the exo- and endodermis while OsMTP9 is expressed on the opposite site of the cell as NRAMP5. This polar arrangement ensures radial transport of Mn toward the xylem. (A) Field trials show that loss of function in NRAMP5 greatly reduces Cd levels in roots, shoots and grains but it also compromises Mn uptake, making this approach viable only in the presence of sufficient Mn. Other micronutrients were not affected and no yield penalty was observed (based on data from Tang et al, 2017). (B) The use of strong promoters can disrupt the expression tissue patterns and polar arrangement of transporters and thereby disrupt radial transport toward the xylem. Hence,overexpression of NRAMP5, paradoxically, also reduced Cd levels of the grain. In this case, Mn provision to the shoot remained largely intact since MTP9 does not transport Cd (based on data from Chang et al., 2020).

\section{Hosted file}

image1.emf available at https://authorea.com/users/420529/articles/526859-the-role-of-rootsand-rhizosphere-in-providing-tolerance-to-toxic-metals-and-metalloids

\section{Hosted file}

image2.emf available at https://authorea.com/users/420529/articles/526859-the-role-of-rootsand-rhizosphere-in-providing-tolerance-to-toxic-metals-and-metalloids

\section{Hosted file}

image3.emf available at https://authorea.com/users/420529/articles/526859-the-role-of-rootsand-rhizosphere-in-providing-tolerance-to-toxic-metals-and-metalloids

\section{Hosted file}

image4.emf available at https://authorea.com/users/420529/articles/526859-the-role-of-rootsand-rhizosphere-in-providing-tolerance-to-toxic-metals-and-metalloids

Table 1: Results from a literature search on studies of heavy metal(loid) tolerance in the field. The ISI database was queried ${ }^{1)}$ for works that evaluated alterations in 'Membrane transport', 'Rhizosphere', 'Root architecture' or metal 'Chelation/Sequestration' in actual field trials. Searches were done separately for As, Cd, Hg and Zn spanning 2008 to 2021.

\begin{tabular}{lll}
\hline Tolerance mechanism: & Membrane transport & Rhizosphere microbial communities \\
Reference: & Lu et al., 2019 & \\
& Tang et al., 2017 \\
& Chang et al., 2020 \\
& Ma et al., 2008
\end{tabular}

Nong et al., 2020

Hui et al., 2015

Gao et al., 2010

Wu et al., 2011

1) Search terms ' $x+$ tolerance+field trial' were used where ' $x$ ' is As, Cd, Hg or Zn respectively. Within the search output, papers were included that were based on one or more of the following strategies: 'Metal(loid) liganding and vacuolar sequestration'; 'Alteration of transport'; 'Changes in root morphology/architecture'; or 'Effects on plant tolerance of plant-growth-promoting rhizobacteria/fungi'. 